\title{
Benefits of Risk-Sharing in the Structuring of Șukūk
}

\author{
Abdul Karim Abdullah (Leslie Terebessy)*
}

Several cases of șuku $k^{1}$ defaults and near defaults have occurred recently. In Malaysia, according to the Securities Exchange Commission, seven șukük with a combined value of more than RM740 million, have defaulted. Șukük issued by the Saad Group of Saudi Arabia, Dar Investment Group, the International Investment Group of Kuwait, East Cameron Partners in the United States and others also defaulted. In December 2009, several șukūk issued by Dubai World and its subsidiaries nearly defaulted. Was the way the șukūk were structured among the reasons for the defaults, as alleged by some, or were the șukūk investors simply the victims of the larger global economic and financial crisis?

There is no denying that the global economic and financial crisis played a key role in the defaults and near defaults. Upon closer inspection, however, one finds that the way the suku $\bar{k}$ were structured also played a part. It is clear that the vast majority of sukūk were structured to mimic conventional bonds. It hardly comes as a surprise, therefore, that they also replicated some of the risks that also face buyers of conventional bonds, albeit in an altered form, in particular the risk of default. With respect to $s u k \bar{u} k$, the risk of default is better known as 'asset redemption risk'.

$S$ Suku $k$ which defaulted or nearly defaulted imitated conventional bonds in two fundamental respects. They were structured to pay predetermined dividends (to produce a 'fixed income' instrument) and to return the initial amount invested to the $s ̧ u k \bar{u} k$ holders in one lump sum on the maturity date of the șukukk. In conventional finance, the action of returning to creditors the principal amounts they lent to borrowers by buying bonds is known as 'redeeming' the bonds. The process of returning to șukūk buyers the initial amount they invested by buying the șukukk took place by means of 'repurchasing' the underlying assets on the day the șukūk 'matured'. The obligation to repurchase the underlying assets, which was inserted into the șukūk contract, created an 'amount owing' by șukūk issuers to the șukūk holders. This obligation to 'repay' a large amount of capital on the maturity date of the sukukk by repurchasing the underlying assets put enormous pressure on the issuers to ensure that they had the necessary funds ready to 'redeem' the șukukk. Those which did not have this amount ready, for whatever reasons, either 'defaulted' or nearly defaulted.

Neither of the two features that sukü $k$ share with conventional bonds characterises genuine risk-sharing instruments, such as ordinary company shares. To promise

* Abdul Karim Abdullah (Leslie Terebessy) is Assistant Research Fellow at IAIS Malaysia.

ICR 2.3 Produced and distributed by Pluto Journals ICR.plutojournals.org 
predetermined 'dividends' to investors in an uncertain economic environment, even if the dividends are pegged to an 'Islamic' benchmark, and to require the issuer to 'repay' the initial amount invested to șukuk holders, has the effect of shifting the risk of losses squarely onto one party - the issuer. Such an arrangement can by no stretch of the imagination be viewed as a risk-sharing partnership. Suk $u \bar{k}$ of this nature are better described as risk-shifting instruments, similar to conventional bonds. Like conventional bonds, they shift risk from the investor to the issuer.

In bona fide risk-sharing relationships the counterparties are partners, such as in a mudārabah or a mushārakah. They share both the good times and the bad. In creditor-debtor relationships, a basic inequality characterises the relationship between the counterparties, where the creditor usually holds the upper hand. Conventional creditors are basically fair-weather friends. They wish to share gains, but not losses.

Moreover, in the great majority of $s u k \bar{u} k$ issues the legal ownership of the underlying assets remained with the originators. The șuku $k$ holders became merely the 'beneficial' rather than legal owners of the underlying asset. 'Beneficial' ownership characterises about 90 per cent of all șukük issued. The concept of beneficial ownership entitles one to the ownership of the usufruct of an asset (such as rent), but not of the asset itself.

$S u k u \bar{k}$ which confer merely 'beneficial' ownership of the underlying assets on the $s u k \bar{u} k$ holders are known as 'asset-based' șukuk.$S u k \bar{u} k$ where the legal ownership of the underlying assets is transferred to the sukūk holders, on the contrary, are known as "asset-backed" șukūk. These constitute only about 10 per cent of all șukūk issued.

Asset-based șukūk are similar to conventional unsecured bonds. Asset-backed $s ̧ u \bar{u} k$ resemble conventional secured loans. The difference between the two may seem unimportant during normal times, but attains a decisive significance in times of distress, when the prospect of a bankruptcy of the issuer may be looming on the horizon and thus present great risks to $s u k \bar{u} k$ holders.

\section{Some Recommendations}

- In the interests of transparency and investor protection, it is necessary that $s u k \bar{u} k$ contracts clearly stipulate whether the $s u k \bar{u} k$ being marketed to investors are asset-backed or asset-based. Not specifying whether șukūk holders are the legal owners of the underlying assets, whether by means of a bankruptcy remote SPV acting on their behalf or in some other way, and therefore become entitled to claim the underlying assets in case of default by the issuer as a way of recovering their investments, considerably reduces the transparency of the $s u k \bar{u} k$ contract. It creates uncertainty for the investors, as they will be left in 
the dark as to whether they are buying secured (asset-backed) or unsecured (asset-based) șukūk.

- Structuring șukūk to mimic conventional bonds exposes buyers of șukūk to risks that are nearly identical to the risks facing buyers of conventional bonds, in particular the risk of default. In order to enhance investor protection, it is necessary to structure șukukk as genuine risk-sharing instruments. In such instruments, the risk of default does not arise in the first place.

- The way forward is to utilise genuine risk-sharing vehicles such as mushārakah and mudārabah. Issuers may initially raise less money, but in all likelihood whatever funds are raised will be used more efficiently and wisely. In the interest of greater stability in the longer term, it may well be worth making a short-term sacrifice implied by making the required paradigm shift in the structuring of șukūk toward risk-sharing instruments such as the mud̄arabah and the mushärakah.

\section{Note}

1. Şukūk (pl. of șakk, 'legal instrument', 'deed', 'check') is the Arabic name for financial certificates, but commonly refers to the Islamic equivalent of bonds. Since 'fixed income', interest-bearing bonds are not permissible in Islam, șukük securities are structured to comply with the sharí' $a h$ and its investment principles, which prohibit the charging, or paying of interest. 